\title{
Derivation of Necessary Items for Implementation of Gardens in Urban Agricultural Parks
}

\author{
In-Kyoung Hong ${ }^{1}$, Young-Bin Jung ${ }^{2 *}$, Hyung Kwon Yun ${ }^{3}$, and Sang-Mi Lee ${ }^{2}$ \\ ${ }_{1}^{1}$ Postdoctoral researcher, Urban Agricultural Research Division, National Institute of Horticultural and Herbal Science, Rural Development \\ Administration, Wanju-gun, Jeolabuk-do 55365, Korea \\ ${ }^{2}$ Researcher, Urban Agricultural Research Division, National Institute of Horticultural and Herbal Science, Rural Development Administration, \\ Wanju-gun, Jeolabuk-do 55365, Korea \\ ${ }^{3}$ Senior researcher, Urban Agricultural Research Division, National Institute of Horticultural and Herbal Science, Rural Development \\ Administration, Wanju-gun, Jeolabuk-do 55365, Korea
}

\section{ABSTRACT}

Background and objective: This study was conducted to obtain empirical data for deriving necessary items for the creation and management of gardens in urban agricultural parks while maintaining the publicness of the place by examining the difference in perception among park visitors about the gardens in the public parks.

Methods: A survey was conducted on users of urban agricultural parks in 6 locations and 113 copies of the questionnaire were collected. After understanding the demographic characteristics and the current use of the garden, we identified the importance of the necessary items for the public gardens.

Results: 108 subjects(95.6\%) responded that gardens are needed in urban parks, for psychological and emotional health (26.2\%) and for interaction and friendship with family and neighbors(23.2\%). For use of garden crops, most were private sales(96 subjects, $64.4 \%$ ), and both sales preferred to partially donate their crops. Most used communal gardens operated by public institutions(30.1\%). It was found that $96.4 \%$ of the respondents were satisfied with gardening activities, and 107(94.7\%) of them showed their intention to participate in the gardening in the future. The Kaiser Meyer Olkin value was .848 and the significance level was .001, proving the validity of factor analysis. The factors were named composition elements(Factor 1), management items(Factor 2), convenience elements(Factor 3), and operational facilities(Factor 4). In the survey on the creation and management of gardens in urban agricultural parks, there were no statistically significant differences, but all items had correlations.

Conclusion: The results have reflected the needs of actual users in establishing the plans to operate urban gardens, thereby having great utility value as the basic data for continuous garden management. Further research can be conducted to derive detailed elements that can guarantee sustainability of urban gardens and suggest high-quality data for management of gardens in urban agricultural parks.

Keywords: creation and operation, intent to participation, promoting publicness, satisfaction, urban garden

\section{Introduction}

Urban agriculture, which is rising as a matter of global interest among many countries of the world, cultivates the community spirit by making the city healthy, forming communities, and communicating and collaborating beyond just farming (Yoo, 2014). In the modern society, urban residents are showing more interest in agricultural activities along with nostalgia for rural areas. This tendency is found in the form of agricultural activities such as using gardens to grow vegetables and flowers at home or participating in tourism agriculture or farming programs, as well as vari-

This study is funded by the Rural Development Administration project (PJ014385012021).

Received: May 19, 2021, Revised: June 15, 2021, Accepted: July 9, 2021

First author: In-Kyoung Hong, inkyoung63@korea.kr, (1) https://orcid.org/0000-0002-7050-5413

*Corresponding author: Young-Bin Jung, jybin77@korea.kr, (1D) https://orcid.org/0000-0003-3287-8451 
ous forms of urban agriculture such as community recovery and urban regeneration for life quality improvement with a better understanding of agriculture along with pleasure from gardening activities (Lee, 2015).

According to the Act on Development and Support of Urban Agriculture, urban agriculture is defined as 'activities prescribed by Presidential Decree such as growing or cultivating crops using land, buildings, or various living spaces in an urban area'. Urban agricultural parks can be registered as theme parks through the Act on Urban Parks, Green Areas, etc. amended on November 23, 2013, and the park area can exceed $10,000 \mathrm{~m}^{2}$ without limits to establishment criteria and effective distance. Since the amendment, urban agricultural parks include gardens as facilities that help urban agricultural activities, and thus careful approach is needed in terms of various interests and agents of cultivation. Accordingly, it is important to find the direction for implementation of gardens in urban agricultural parks that can minimize conflicts among users in order to maintain publicness of the parks.

Urban agricultural parks are public places for citizens to have fun or relax, where various social activities take place while also improving the urban environment, and require publicness as public goods for people of all levels of society (Nam, 2014). Moreover, these parks have been newly introduced in the process of promoting urban agriculture and have significance as parks that provide exhibitions for general visitors and convenience for citizens to relax, beyond just serving as garden space for urban agriculture (Oh, 2012). The recent need for quality life and change in social awareness about the environment have led urban residents to demand publicness of urban space. As the promotion of urban agriculture has enabled installation of facilities for urban agriculture in parks, local governments are seeking ways to implement park-style urban agriculture. However, there is a difficulty in securing project sites, insufficient supply to meet the demand, and need to improve project sustainability (Oh et al., 2013). Citizens using the park may also feel hostile to the idea of agricultural activities in the park or have a negative perception that only specific people participate (Nam, 2014). Measures must be taken urgently to resolve these issues. Therefore, urban agricultural parks must have accessibility, openness, comfort, and regionality in terms of urban publicness, and require consideration of awareness about participant independence, community activities, and council formation (Lee, 2015).

This study examines the difference in park users' perception of gardens in urban agricultural parks to obtain empirical data on finding ways to introduce and manage gardens while maintaining publicness of parks so that there are no functional conflicts between the two. To this end, based on general understanding of urban agriculture, this study will find necessary items for creating and managing gardens in urban agricultural parks by conducting a survey on park users to identify the current state of gardens in urban agricultural parks through empirical research.

\section{Research Methods}

\section{Subjects}

This study is conducted to find ways to create and manage urban gardens in urban agricultural parks. Accordingly, to identify the current state of public gardens in urban agricultural parks, a survey was conducted from July 3 to 15 (13 days), 2019 by selecting users of 6 urban agricultural parks in Seoul, Gyeonggi, and Jeolla with convenience sampling.

\section{Questionnaire design}

\section{Structure}

There were total 40 items: 6 items on demographic characteristics, 2 items on the need for gardens in urban agricultural parks and reason, 3 items on utilization of gardens, 11 items on use of gardens, 11 items on creation of public urban gardens, and 7 items on management of public urban gardens (Table 1). It was a self-administered survey in which respondents are given enough explanation of the purpose and contents of the survey and answer the questions themselves.

\section{Measurement items}

To conduct this study, we requested data on the manage- 
Table 1. Organization of survey items

\begin{tabular}{|c|c|c|c|c|}
\hline No. & Item & Contents & No. of Item & Reference \\
\hline DV1-DV4 & Demographic characteristics & $\begin{array}{l}\text { Gender, Age, Highest level of education, Number of } \\
\text { locations by region, Housing type, Gardening experience }\end{array}$ & 6 & $\operatorname{Nam}(2014)$ \\
\hline V1-V2 & Awareness of the urban garden & $\begin{array}{l}\text { Whether and Why there is a need for a garden the urban } \\
\text { agricultural park }\end{array}$ & 2 & Nam (2014) \\
\hline V3-V5 & How to utilize a garden & $\begin{array}{l}\text { How to use the garden in the urban agricultural park, and the } \\
\text { harvest for individual and group sales }\end{array}$ & 3 & $\operatorname{Nam}(2014)$ \\
\hline V6-V16 & Survey on use of garden & $\begin{array}{l}\text { Current use of urban gardens, Garden type, Number of visit, } \\
\text { Day of visit, Time spent in the garden, Participants, } \\
\text { Interaction between users, How to use the harvest, } \\
\text { Satisfaction, Future intention to participate. }\end{array}$ & 11 & $\begin{array}{l}\text { Hong et al. (2018), } \\
\text { Nam (2014) }\end{array}$ \\
\hline V17-V27 & $\begin{array}{l}\text { Creation of public urban } \\
\text { gardens }\end{array}$ & Main items for gardening & 11 & $\begin{array}{l}\text { Yoo (2014), } \\
\text { Nam (2014) }\end{array}$ \\
\hline V28-V34 & $\begin{array}{l}\text { Management of public urban } \\
\text { gardens }\end{array}$ & Main items for garden operation & 7 & $\begin{array}{l}\text { Yoo (2014), } \\
\text { Nam (2014) }\end{array}$ \\
\hline
\end{tabular}

Table 2. Items required for the creation and management of a garden in the urban agricultural parks.

\begin{tabular}{cc}
\hline Item & Necessary items for urban garden \\
x1 & Accessibility \\
x2 & Parking space \\
x3 & Resting shade and rest area \\
x4 & Farm equipment storage facilities \\
x5 & Watering fountains and irrigation facilities \\
x6 & Resource-utilized composting facilities \\
x7 & Garden size \\
x8 & Garden design and space design \\
x9 & Fence and boundary between gardens \\
x10 & Convenience facilities for the disabled \\
x11 & Animal breeding facilities \\
x12 & Garden operation and manpower \\
x13 & Regulations and finances \\
x14 & Urban garden usage fee \\
x15 & Urban garden usage period \\
x16 & Small group among users \\
x17 & Community program for users \\
x18 & Cocation program related to garden cultivation \\
\hline
\end{tabular}

${ }^{\mathrm{z}}$ Items were arbitrary variable name indicating the necessary items for creation and management of garden in urban agricultural parks.

ment of departments related to urban agriculture in Korea in January 2019 and restructured the questionnaire based on the collected data and previous studies. We came up with total 18 items necessary for creation and management of urban gardens and rated each item on a 5-point Likert scale from 1 point 'Not important at all', 2 points 'Not important', 3 points 'Neutral', 4 points 'Important', and 5 points 'Very important' (Table 2).

\section{Analysis method}

Total 189 copies of the questionnaire were distributed 
on site, 113 copies of which were retrieved. They were totaled and organized on Excel and analyzed using IBM SPSS statistics Ver. 25. Frequency analysis and descriptive analysis were conducted on demographic characteristics of the subjects and contents about use of gardens. Validity of measurement variables was tested to extract necessary items for creation and management of public urban gardens, and exploratory factor analysis was conducted to classify the factors. Cronbach's alpha was calculated through reliability analysis to test the internal consistency. Factors were extracted with varimax rotation using principal component analysis, extracting only factors with an eigenvalue greater than 1 to classify the factors. Moreover, to determine the relationship of necessary items for creation and management of public gardens, we conducted one-way ANOVA, a statistical method to test the difference in means of samples. Then we tested the significance at $95 \%$ confidence level $(p<.05)$ using Duncan's multiple range test and obtained Pearson's R, which is the correlation coefficient of variables, for correlation analysis to determine the correlation among the derived items.

\section{Results and Discussion}

\section{Demographic characteristics of respondents}

There were 47 men (41.6\%) and 66 women (58.4\%), and none of them were under 20; 41 respondents were in their 50s (36.3\%), followed by 34 in their 40 s $(30.1 \%)$ $>20$ in their $60 \mathrm{~s}(17.7 \%)>9$ in their $30 \mathrm{~s}(8.0 \%)>7$ in their $70 \mathrm{~s}(6.2 \%)>2$ in their $20 \mathrm{~s}(1.8 \%)$. The highest level of education for most respondents was university enrollment/graduation (41.6\%), followed by high school graduation $(32.7 \%)>$ college enrollment/graduation $(12.4 \%)>$ graduate school enrollment/graduation $(7.1 \%)>$ middle school graduation $(4.4 \%)>$ elementary school graduation and others $(0.9 \%)$. Most of them had 4 household members (44 subjects, $38.9 \%$ ), followed by 3 members $(22.1 \%)>$ 2 members $(18.6 \%)>1$ member $(8.8 \%)>5$ members $(7.1 \%)$ $>6$ members $(1.8 \%)>7 / 10 / 20$ members $(1$ each, $0.9 \%)$. Most of the respondents lived in apartments of 5 stories or more ( 86 , subjects, $76.1 \%$ ), followed by multi-family or row houses of 4 stories or less $(12.4 \%)>$ detached houses $(11.5 \%)$. Regarding gardening experience, 83 subjects responded that they are 'doing it now' (73.5\%), followed by 'I' ve done it before, but not now' $(16.8 \%)>$ 'never did' $(8.0 \%)>$ others $(1.8 \%)$ (Table 3$)$. This result is consistent with the study by Hong et al. (2021) reporting that $73.5 \%$ of respondents have gardening experience. Considering the increase in the area of urban agriculture and the number of participants every year, participation in urban agricultural activities will continue to grow.

\section{Survey on the awareness on the use of gardens in urban agricultural parks}

\section{Awareness on the creation of gardens in urban agricultural parks}

To determine the fundamental problems in adopting gardens in urban agricultural parks, it is necessary to first identify the difference in the awareness among park users. Accordingly, the items here are on the need to create gardens and why. 108 subjects $(95.6 \%)$ responded that gardens in urban agricultural parks are necessary, while 5 (4.4\%) responded they are not necessary. With the average score of 4.57 points, this result was consistent with the studies by Nam (2014) and Yun (2020) who emphasized the need to create gardens in parks. As a result of multiple response analysis on the reason why gardens are needed in urban parks, most subjects responded that they are necessary for psychological and emotional health of urban residents (86 subjects, 26.2\%) and for interaction and friendship with family and neighbors $(76,23.2 \%)$, followed by physical exercise of urban residents $(14.6 \%)>$ safe food production $(12.5 \%)>$ children's education and learning $(11 \%)>$ acquisition of plant cultivation methods and improvement of urban aesthetics $(5.2 \%)>$ reduction of vegetable purchase costs $(1.8 \%)>$ others $(0.3 \%)$. This was similar to the study by Kim (2013) claiming that communication through gardening activities or space to cultivate crops provides an opportunity for urban residents to be satisfied with their surroundings and stabilize their emotions. The urban park with most participation was Hamjul (26, 23.0\%), followed by IIlwol $(19.5 \%)>$ Baegot $(18.6 \%)>$ Sindae $(16.8 \%)>$ Yangcheon $(15.0 \%)>$ Gangdong (7.1\%) (Table 4). 
Table 3. The respondent's demographic characteristics.

\begin{tabular}{|c|c|}
\hline Item & $\begin{array}{c}\text { No. of } \\
\text { respondents } \\
(\%)\end{array}$ \\
\hline \multicolumn{2}{|l|}{ Gender } \\
\hline Male & $47(41.6)$ \\
\hline Female & $66(58.4)$ \\
\hline Total & $113(100.0)$ \\
\hline \multicolumn{2}{|l|}{ Age } \\
\hline $20 \mathrm{~s}$ & $2(1.8)$ \\
\hline $30 \mathrm{~s}$ & $9(7.9)$ \\
\hline $40 \mathrm{~s}$ & $34(30.1)$ \\
\hline $50 \mathrm{~s}$ & $41(36.3)$ \\
\hline $60 \mathrm{~s}$ & $20(17.7)$ \\
\hline $70 \mathrm{~s}$ & $7(6.2)$ \\
\hline Total & $113(100.0)$ \\
\hline \multicolumn{2}{|l|}{ Highest level of education } \\
\hline Elementary school graduation & $1(0.9)$ \\
\hline Middle school graduation & $5(4.4)$ \\
\hline High school graduation & $37(32.7)$ \\
\hline College enrollment/graduation & $14(12.4)$ \\
\hline University enrollment/graduation & $47(41.6)$ \\
\hline Graduate school graduation & $8(7.1)$ \\
\hline Other & $1(0.9)$ \\
\hline Total & $113(100.0)$ \\
\hline \multicolumn{2}{|l|}{ Number of household members } \\
\hline 1 & $10(8.8)$ \\
\hline 2 & $21(18.6)$ \\
\hline 3 & $25(22.1)$ \\
\hline 4 & $44(38.9)$ \\
\hline 5 & $8(7.1)$ \\
\hline 6 & $2(1.8)$ \\
\hline 7 & $1(0.9)$ \\
\hline 10 & $1(0.9)$ \\
\hline 20 & $1(0.9)$ \\
\hline Total & $113(100.0)$ \\
\hline \multicolumn{2}{|l|}{ Housing type } \\
\hline Detached house & $13(11.5)$ \\
\hline Multi-family or row house (4 stories or less) & $14(12.4)$ \\
\hline Apartment ( 5 stories or more) & $86(76.1)$ \\
\hline Total & $113(100.0)$ \\
\hline \multicolumn{2}{|l|}{ Gardening experience } \\
\hline Doing it now & $83(73.4)$ \\
\hline I've done it before, but I don't now & $19(16.8)$ \\
\hline Never did & $9(8.0)$ \\
\hline Other & $2(1.8)$ \\
\hline Total & $113(100.0)$ \\
\hline
\end{tabular}

Table 4. Awareness on the creation of gardens in urban agricultural parks.

\begin{tabular}{lc}
\hline \multicolumn{1}{c}{ Item } & $\begin{array}{c}\text { No. of } \\
\text { respondents } \\
(\%)\end{array}$ \\
\hline Need a garden in the urban agricultural park & $108(95.6)$ \\
\hline Yes & $5(4.4)$ \\
No & $113(100.0)$ \\
\hline Total & $41(12.5)$ \\
\hline Reasons for needing a garden in the urban agricultural park \\
Safe food production & $48(14.6)$ \\
Physical exercise effect & $86(26.2)$ \\
Psychological and emotional health & $76(23.2)$ \\
Exchange and friendship with family and neighbors & $17(5.2)$ \\
Acquisition of plant cultivation & $36(11.0)$ \\
Education and learning of children & $6(1.8)$ \\
Reduction of vegetable purchase costs & $17(5.2)$ \\
Improvement of urban aesthetics & $1(0.3)$ \\
Other & $328(100.0)$ \\
\hline Total & \\
\hline Number of surveys by urban agricultural park & $17(15.0)$ \\
Yangcheon (Seoul) & $26(23.0)$ \\
Hamjul (Seoul) & $19(16.8)$ \\
Sindae (Suncheon) & $8(7.1)$ \\
Gangdong (Seoul) & $22(19.5)$ \\
Ilwol (Kyunggi-do, Suwon) & $21(18.6)$ \\
Baegot (Seoul) & $113(100.0)$ \\
\hline Total &
\end{tabular}

\section{Survey on how to use garden crops}

As a result of multiple response analysis on selling the gardens in urban agricultural parks, most were private sales (96 subjects, $64.4 \%$ ), followed by group sales $(33.6 \%)>$ others $(2.0 \%)$. In case of private sales, crops were mostly used by partial donation (61 subjects, $54.0 \%$ ), followed by individual use $(42,37.2 \%)>$ full donation and others $(5$, $4.4 \%)$. In case of group sales, crops were mostly used by partial donation (58 subjects, 51.3\%), followed by group use $(36,31.9 \%)>$ full donation $(19,16.8 \%)$, indicating that both individuals and groups donated part of the crops while the producers used the rest (Table 5). This result is similar to the study by Yun (2020) claiming that some must be self-consumed and some shared. This is due to the increase in single-person households and the payment of fees for gardens in urban agricultural parks. 
Table 5. How to use garden crops in urban agricultural parks.

\begin{tabular}{lc}
\hline \multicolumn{1}{c}{ Item } & $\begin{array}{c}\text { No. of } \\
\text { respondents } \\
(\%)\end{array}$ \\
\hline Urban agricultural park garden utilization plan \\
Private sale \\
Group sale & $96(64.4)$ \\
Etc & $50(33.6)$ \\
Total & $3(2.0)$ \\
Measures to utilize harvested products of private sale & $149(100.0)$ \\
Individual use & $42(37.2)$ \\
Partial donation & $61(54.0)$ \\
All donation & $5(4.4)$ \\
Others & $5(4.4)$ \\
\hline Total & $113(100.0)$ \\
\hline Measures to utilize harvested products of group sale & \\
Group use & $36(31.9)$ \\
Partial donation & $58(51.3)$ \\
All donation & $19(16.8)$ \\
\hline Total & $113(100.0)$ \\
\hline
\end{tabular}

\section{Survey on the use of gardens in urban agricultural parks}

As a result of the survey on the use of gardens in urban parks, 83 subjects $(73.5 \%)$ responded that they are currently using the gardens, and 25 subjects (30.1\%) used communal gardens operated by public institutions, followed by individual cultivation $(20.5 \%)>$ urban agricultural parks $(19.3 \%)>$ communal gardens operated by individuals $(15.7 \%)$ $>$ communal gardens operated by civic groups $(13.3 \%)>$ others (1.2\%). 37 subjects used the garden 2-3 times a week (44\%), followed by almost every day $(21.4 \%)>$ once a week $(17.9 \%)>4-5$ times a week $(14.3 \%)>$ twice and once a month each $(1.2 \%)$, showing similar results with studied by Nam (2014) and Chae et al. (2019). Most used the garden on Saturdays (21.3\%), followed by Sundays $(16.3 \%)>$ Tuesdays $(14.8 \%)>$ Fridays $(14.1 \%)>$ Mondays and Wednesdays $(11.8 \%)>$ Thursdays $(9.9 \%) .38$ subjects spent 1-2 hours in the garden (46.3\%), followed by less than 1 hour $(34.1 \%)>2-3$ hours $(17.1 \%)>3-4$ hours $(2.4 \%)$. 22 subjects participated in gardening activities alone (26.5\%), followed by couple $(25.3 \%)>$ family (with children) $(22.9 \%)$ $>$ with friends or colleagues $(12.0 \%)>$ with neighbors $(10.8 \%)$ $>$ others (2.4\%). The percentage of family was $48.2 \%$ over-
Table 6. Survey on the use of gardens in urban agricultural parks.

\begin{tabular}{|c|c|}
\hline Item & $\begin{array}{c}\text { No. of } \\
\text { respondents } \\
(\%)\end{array}$ \\
\hline \multicolumn{2}{|l|}{ Current use of urban garden } \\
\hline Yes & $96(73.5)$ \\
\hline No & $30(26.5)$ \\
\hline Total & $113(100.0)$ \\
\hline \multicolumn{2}{|l|}{ Garden type } \\
\hline Individual cultivation & $17(20.5)$ \\
\hline Communal gardens operated by individuals & $13(15.7)$ \\
\hline Communal gardens operated by civic groups & $11(13.3)$ \\
\hline $\begin{array}{l}\text { Communal gardens operated by public } \\
\text { institutions }\end{array}$ & $25(30.1)$ \\
\hline Urban agricultural park & $16(19.3)$ \\
\hline Etc & $1(1.2)$ \\
\hline Total & $83(100.0)$ \\
\hline \multicolumn{2}{|l|}{ Number of visit } \\
\hline Almost every day & $18(21.4)$ \\
\hline once a week & $15(17.9)$ \\
\hline 2-3 times a week & $37(44.0)$ \\
\hline $4-5$ times a week & $12(14.3)$ \\
\hline More than once a month & $1(1.2)$ \\
\hline More than twice a month & $1(1.2)$ \\
\hline Total & $84(100.0)$ \\
\hline \multicolumn{2}{|l|}{ Visit day } \\
\hline Monday & $31(11.8)$ \\
\hline Tuesday & $39(14.8)$ \\
\hline Wednesday & $31(11.8)$ \\
\hline Thursday & $26(9.9)$ \\
\hline Friday & $37(14.1)$ \\
\hline Saturday & $56(21.3)$ \\
\hline Sunday & $43(16.3)$ \\
\hline Total & $263(100.0)$ \\
\hline \multicolumn{2}{|l|}{ Time spent in the garden } \\
\hline Less than one hour & $28(34.2)$ \\
\hline $1 \sim 2$ hours & $38(46.3)$ \\
\hline $2 \sim 3$ hours & $14(17.1)$ \\
\hline $3 \sim 4$ hours & $2(2.4)$ \\
\hline Total & $82(100.0)$ \\
\hline \multicolumn{2}{|l|}{ Participants } \\
\hline Alone or Spouse alone & $22(26.5)$ \\
\hline Couple & $21(25.3)$ \\
\hline Family (with children) & $19(22.9)$ \\
\hline With neighbors & $9(10.8)$ \\
\hline With friends or colleagues & $10(12.0)$ \\
\hline Others & $2(2.4)$ \\
\hline Total & $83(100.0)$ \\
\hline
\end{tabular}


Table 6. (continued)

\begin{tabular}{|c|c|}
\hline Item & $\begin{array}{c}\text { No. of } \\
\text { respondents } \\
(\%)\end{array}$ \\
\hline \multicolumn{2}{|l|}{ Interaction between users } \\
\hline Dont' know & $4(4.8)$ \\
\hline Only know faces & $10(12.0)$ \\
\hline Greet each other & $18(21.7)$ \\
\hline Talk to each other & $46(55.4)$ \\
\hline Meet regularly & $5(6.0)$ \\
\hline Total & $83(100.0)$ \\
\hline \multicolumn{2}{|l|}{ How to use the harvest } \\
\hline Use at home & $7(8.4)$ \\
\hline Share with family+friends & $27(32.5)$ \\
\hline Share with family + neighbors & $38(45.8)$ \\
\hline Donate to local facilities or institutions & $11(13.3)$ \\
\hline Total & $83(100.0)$ \\
\hline \multicolumn{2}{|l|}{ Satisfaction after gardening activities } \\
\hline Very satisfied & $60(72.3)$ \\
\hline Satisfied & $20(24.1)$ \\
\hline Normal & $3(3.6)$ \\
\hline Total & $83(100.0)$ \\
\hline \multicolumn{2}{|l|}{ Future intention to participate in urban gardens } \\
\hline Yes & $107(94.7)$ \\
\hline No & $6(5.3)$ \\
\hline Total & $113(100.0)$ \\
\hline
\end{tabular}

all, which showed a similar result with studies by Nam (2014) and Yun (2020) proving that participants were most accompanied by family. This raises the need to create a place that combines education and rapport and to design a garden in which all urban residents can participate together by developing various programs that reflect the changing social structure. 26 subjects responded that they interact by talking to one another (55.4\%), followed by just greeting one another $(21.7 \%)>$ only recognizing faces $(12.0 \%)>$ meeting regularly $(6.0 \%)>$ don't know $(4.8 \%) .38$ subjects (45.8\%) responded that they share the harvested crops with family and neighbors, followed by sharing with family and friends $(32.5 \%)>$ donating to local facilities or institutions $(13.3 \%)>$ using at home $(8.4 \%)$, showing similar results with studies by Hong et al. (2021), Chae et al. (2019), and Park et al. (2016). 72.3\% were very satisfied after urban gardening activities, $24.1 \%$ were satisfied, and $3.6 \%$
Table 7. Factor analysis in necessary items for creation and management of gardens in urban agraicultural parks.

\begin{tabular}{|c|c|c|c|c|c|}
\hline \multirow{2}{*}{ Factors } & \multirow{2}{*}{ Item $^{\mathrm{z}}$} & \multicolumn{4}{|c|}{ Division } \\
\hline & & 1 & 2 & 3 & 4 \\
\hline \multirow{7}{*}{1} & $\mathrm{x} 9$ & .749 & & & \\
\hline & $\mathrm{x} 7$ & .720 & & & \\
\hline & $\mathrm{x} 10$ & .716 & & & \\
\hline & x11 & .692 & & & \\
\hline & $\mathrm{x} 8$ & .669 & & & \\
\hline & $\mathrm{x} 12$ & .615 & & & \\
\hline & $\mathrm{x} 1$ & .522 & & & \\
\hline \multirow{5}{*}{2} & $\mathrm{x} 18$ & & .822 & & \\
\hline & $\mathrm{x} 17$ & & .742 & & \\
\hline & x14 & & .634 & & \\
\hline & $\mathrm{x} 16$ & & .594 & & \\
\hline & $\mathrm{x} 15$ & & .556 & & \\
\hline \multirow{3}{*}{3} & $\mathrm{x} 3$ & & & .744 & \\
\hline & $\mathrm{x} 2$ & & & .739 & \\
\hline & $\mathrm{x} 13$ & & & .613 & \\
\hline \multirow{3}{*}{4} & $\mathrm{x} 6$ & & & & .824 \\
\hline & $\mathrm{x} 4$ & & & & .680 \\
\hline & $x 5$ & & & & .512 \\
\hline \multicolumn{5}{|c|}{ Kaiser-Meyer-Olkin measure of sampling adequancy } & .848 \\
\hline \multirow{3}{*}{\multicolumn{2}{|c|}{$\begin{array}{l}\text { Bartlett's test of } \\
\text { sphericity }\end{array}$}} & \multicolumn{2}{|c|}{$\chi^{2}$} & \multicolumn{2}{|c|}{982.984} \\
\hline & & \multicolumn{3}{|c|}{ df } & 153 \\
\hline & & \multicolumn{3}{|c|}{ Significant } & .001 \\
\hline
\end{tabular}

were neutral, showing that most subjects were satisfied. 107 subjects $(94.7 \%)$ except for $6(5.3 \%)$ responded that they have the intention to participate in urban gardens in the future, indicating that their interest in urban agricultural activities is constantly growing (Table 6). This is consistent with the report by the Ministry of Agriculture, Food and Rural Affairs (2018) that the area of urban agricultural gardens and the number of participants are increasing.

\section{Survey on necessary items for creation and management of urban gardens}

\section{Factor analysis of necessary items for creation of urban garden}

This study was conducted to come up with necessary items for creation and management of gardens in urban agricultural parks. The results of factor analysis are as shown in Table 7, and KMO, the coefficient determining 
the adequacy of samples as mentioned by Lee (2003), was .848 , and the significance level was .001, showing a value close to 1 and a value over 0.5 and thus proving validity of factor analysis. Accordingly, based on the similarity of extracted items, the factors were named composition elements (Factor 1), management items (Factor 2), convenience elements (Factor 3), and operational facilities (Factor 4). Factor 1 classified importance as a factor and was comprised of fence and boundary between gardens $(x 9)$, garden size $(x 7)$, convenience facilities for the disabled (x10), animal breeding facilities (x11), garden design and space design (x8), garden operation and manpower (x12), accessibility (x1) and was named 'composition elements'. Factor 2 was comprised of community programs for users (x18), education programs related to garden cultivation (x17), urban garden usage fee (x14), small groups among users (x16), urban garden usage period (x15) and was named 'management items'. Factor 3 was comprised of 3 items such as resting shade and rest area (x3), parking space (x2), regulations and finances (x13) and was named 'convenience elements'. Factor 4 was comprised of 3 items such as resource-utilized composting facilities (x6), farm equipment storage facilities (x4), water fountains and irrigation facilities (x5) and was named 'operational facilities'.

\section{Importance of necessary items for creation and management of gardens}

The results of the importance of necessary items for creation and management of urban gardens are as follows. Except for 2.80 points in x11 (animal breeding facilities) out of 18 items, all showed higher scores than 3.0, which is the median of the 5-point Likert scale, indicating that the subjects generally felt that it is necessary to create and manage gardens. The most necessary item was accessibility (4.57) and the least was animal breeding facilities (2.80) (Table 8). This was consistent with the study by Nam (2014), in which the item 'convenient access to the garden from the main entrance of the park' showed the highest mean at 4.12. As a result of one-way ANOVA, except for $x 5$ (water fountains and irrigation facilities), x6 (resource-utilized composting facilities), x10 (convenience facilities for the disabled), y5 (small groups among users), and y7 (com-

Table 8. Importance of necessary items for creation and management of gardens in urban agricultural parks.

\begin{tabular}{|c|c|c|c|c|c|c|c|}
\hline & Item & $\mathrm{N}$ & Mean & S.D & df & $\mathrm{F}$ & Significant \\
\hline $\mathrm{x} 1$ & Accessibility & 113 & 4.57 & .693 & \multirow{18}{*}{$\begin{array}{c}\text { Between groups }=1 \\
\text { Within groups }=111 \\
\text { Total }=112\end{array}$} & .012 & $.912^{\mathrm{NS}}$ \\
\hline $\mathrm{x} 2$ & Parking space & 113 & 4.27 & 1.000 & & .583 & $.447^{\mathrm{NS}}$ \\
\hline $\mathrm{x} 3$ & Resting shade and rest area & 113 & 4.47 & .682 & & .053 & $.818^{\mathrm{NS}}$ \\
\hline $\mathrm{x} 4$ & Farm equipment storage facilities & 113 & 4.35 & .719 & & .239 & $.626^{\mathrm{NS}}$ \\
\hline $\mathrm{x} 5$ & Watering fountains and irrigation facilities & 113 & 4.46 & .732 & & 4.379 & $.039^{*}$ \\
\hline x6 & Resource-utilized composting facilities & 113 & 4.13 & .829 & & 4.202 & $.043^{*}$ \\
\hline$\times 7$ & Garden size & 113 & 3.91 & 1.005 & & 1.360 & $.246^{\mathrm{NS}}$ \\
\hline $\mathrm{x} 8$ & Garden design and space design & 113 & 3.81 & 1.005 & & 1.971 & $.163^{\mathrm{NS}}$ \\
\hline x9 & Fence and boundary between gardens & 113 & 3.55 & 1.149 & & 3.648 & $.059^{\mathrm{NS}}$ \\
\hline $\mathrm{x} 10$ & Convenience facilities for the disabled & 113 & 3.73 & 1.088 & & 11.234 & $.001^{* * *}$ \\
\hline $\mathrm{x} 11$ & Animal breeding facilities & 113 & 2.80 & 1.233 & & 2.206 & $.140^{\mathrm{NS}}$ \\
\hline $\mathrm{x} 12$ & Garden operation and manpower & 113 & 4.35 & .741 & & 1.135 & $.289^{\mathrm{NS}}$ \\
\hline $\mathrm{x} 13$ & Regulations and finances & 113 & 4.35 & .765 & & .187 & $.666^{\mathrm{NS}}$ \\
\hline $\mathrm{x} 14$ & Urban garden usage fee & 113 & 3.99 & .871 & & .250 & $.618^{\mathrm{NS}}$ \\
\hline $\mathrm{x} 15$ & Urban garden usage period & 113 & 4.21 & .796 & & 1.411 & $.238^{\mathrm{NS}}$ \\
\hline $\mathrm{x} 16$ & Small group among users & 113 & 3.91 & .892 & & 5.692 & $.019^{*}$ \\
\hline $\mathrm{x} 17$ & Education program related to garden cultivation & 113 & 4.38 & .736 & & .313 & $.577^{\mathrm{NS}}$ \\
\hline $\mathrm{x} 18$ & Community program for users & 113 & 4.12 & .832 & & 3.968 & $.049^{*}$ \\
\hline
\end{tabular}

NS, ${ }^{* * * *}$ Non-significant, $p<.05,<.001$ by ANOVA test 
munity programs for users) out of 18 items, there was no statistically significant difference.

Urban residents are using urban agricultural parks near their residential areas for leisure and friendship. Accordingly, to promote use of urban agricultural parks and increase citizen satisfaction, it is necessary to consider additional policies to create parks for experience beyond appreciation by setting up a garden for urban agriculture and adding experience-based facilities and contents for continued operation.

\section{Correlation analysis of necessary items for creation and management of gardens}

As a result of obtaining Pearson's R, the correlation coefficient of variables, by selecting necessary items for creation and management of gardens, all items had correlations as shown in Table 9, which is a statistically significant result. However, Kang (2016) claimed that the correlation coefficient below 0.39 has little relevance, and thus the correlation is low. x11 (animal breeding facilities) did not show a statistically significant result with items such as x2 (parking space), x3 (resting shade and rest area), x4 (farm equipment storage facilities), and x5 (water fountains and irrigation facilities). This is because while creation of urban agricultural parks is an important factor for urban residents, they are not interested in parts other than what is actually relevant to them. However, most users of urban agricultural parks are families, and parents with children are anticipating the use of urban agricultural parks as spaces for farm experience, various insects and horticultural experience, and ecological learning. Rather than cramming lectures or education, they want actual agricultural training programs that provide real experience or teach urban residents how to farm.

\section{Conclusion}

This study examines the difference in park users' perception of gardens in urban agricultural parks to obtain empirical data on finding ways to introduce and manage gardens while maintaining publicness of parks so that there are no functional conflicts between the two. To this end, this study identified the current state of public gardens by examining

Table 9. Correlation between necessity items regarding the creation and management of gardens in urban agricultural parks.

\begin{tabular}{|c|c|c|c|c|c|c|c|c|c|c|c|c|c|c|c|c|c|c|}
\hline Item $^{2}$ & $\mathrm{x} 1$ & $\mathrm{x} 2$ & $\mathrm{x} 3$ & $\mathrm{x} 4$ & $\mathrm{x} 5$ & $\mathrm{x} 6$ & $\mathrm{x} 7$ & $\mathrm{x} 8$ & $\mathrm{x} 9$ & $\mathrm{x} 10$ & $\mathrm{x} 11$ & $\mathrm{x} 12$ & $\mathrm{x} 13$ & $\mathrm{x} 14$ & $\mathrm{x} 15$ & $\mathrm{x} 16$ & $\mathrm{x} 17$ & $\mathrm{x} 18$ \\
\hline $\mathrm{x} 1$ & 1 & & & & & & & & & & & & & & & & & \\
\hline $\mathrm{x} 2$ & $.335^{* *}$ & 1 & & & & & & & & & & & & & & & & \\
\hline $\mathrm{x} 3$ & $.283^{* *}$ & $.536^{* *}$ & 1 & & & & & & & & & & & & & & & \\
\hline $\mathrm{x} 4$ & $.221 *$ & $.241 *$ & $.423 * *$ & 1 & & & & & & & & & & & & & & \\
\hline $\mathrm{x} 5$ & $.221 *$ & $.222 *$ & $.350 * *$ & $.366^{* *}$ & 1 & & & & & & & & & & & & & \\
\hline$x 6$ & $.350^{* *}$ & .054 & $.189 *$ & $.415^{* *}$ & $.325^{* *}$ & 1 & & & & & & & & & & & & \\
\hline$x 7$ & $.445^{* *}$ & $.228^{*}$ & $.230^{*}$ & $.217^{*}$ & $.274 * *$ & $.346^{* *}$ & 1 & & & & & & & & & & & \\
\hline $\mathrm{x} 8$ & $.294 * *$ & $.298 * *$ & $.219 *$ & $.216^{*}$ & .178 & $.266^{* *}$ & $.638^{* *}$ & 1 & & & & & & & & & & \\
\hline $\mathrm{x} 9$ & $.313 * *$ & $.268 * *$ & .170 & .055 & $.323 * *$ & $.344 * *$ & $.529 * *$ & $.622^{* *}$ & 1 & & & & & & & & & \\
\hline $\mathrm{x} 10$ & $.409^{* *}$ & $.289 * *$ & $.307^{* *}$ & .148 & $.317 * *$ & $.239 *$ & $.566^{* *}$ & $.574 * *$ & $.571^{* *}$ & 1 & & & & & & & & \\
\hline $\mathrm{x} 11$ & $.230^{*}$ & .153 & .157 & .042 & .164 & $.262 * *$ & $.439 * *$ & $.423^{* *}$ & $.464 * *$ & $.544 * *$ & 1 & & & & & & & \\
\hline $\mathrm{x} 12$ & $.485^{* *}$ & $.441 * *$ & $.295^{* *}$ & $.238^{*}$ & $.313 * *$ & $.302 * *$ & $.533 * *$ & $.411^{* *}$ & $.541 * *$ & $.517^{* *}$ & $.390 * *$ & 1 & & & & & & \\
\hline $\mathrm{x} 13$ & $.335^{* *}$ & $.381^{* *}$ & $.388^{* *}$ & $.279 * *$ & $.288 * *$ & .138 & $.389 * *$ & $.282^{* *}$ & $.250^{* *}$ & $.490 * *$ & $.340 * *$ & $.591 * *$ & 1 & & & & & \\
\hline x14 & .171 & $.290 * *$ & $.292 * *$ & $.262 * *$ & $.314 * *$ & .088 & $.519 * *$ & $.437 * *$ & $.424 * *$ & $.459 * *$ & $.322 * *$ & $.475^{* *}$ & $.487 * *$ & 1 & & & & \\
\hline $\mathrm{x} 15$ & $.282 * *$ & $.400 * *$ & $.341 * *$ & $.383^{* *}$ & $.444 * *$ & .160 & $.426 * *$ & $.374 * *$ & $.379 * *$ & $.408^{* *}$ & $.208 *$ & $.435^{* *}$ & $.407 * *$ & $.673^{* *}$ & 1 & & & \\
\hline $\mathrm{x} 16$ & $.342^{* *}$ & $.207^{*}$ & $.186^{*}$ & $.230^{*}$ & $.391 * *$ & $.414 * *$ & $.449 * *$ & $.499 * *$ & $.448^{* *}$ & $.444 * *$ & $.316^{* *}$ & $.465^{* *}$ & $.385^{* *}$ & $.528 * *$ & $.442 * *$ & 1 & & \\
\hline $\mathrm{x} 17$ & $.222 *$ & $.420 * *$ & $.228^{*}$ & $.250 * *$ & $.368 * *$ & $.238^{*}$ & $.396^{* *}$ & $.459 * *$ & $.332 * *$ & $.444 * *$ & $.352 * *$ & $.412 * *$ & $.352 * *$ & $.465^{* *}$ & $.456^{* *}$ & $.528^{* *}$ & 1 & \\
\hline $\mathrm{x} 18$ & .134 & $.339 * *$ & $.187^{*}$ & $.275^{* *}$ & $.293 * *$ & $.301 * *$ & $.333^{* *}$ & $.453^{* *}$ & $.354 * *$ & $.410^{* *}$ & $.293 * *$ & $.283 * *$ & $.344 * *$ & $.482 * *$ & $.421 * *$ & $.603 * *$ & $.730 * *$ & 1 \\
\hline
\end{tabular}

${ }^{2}$ Items were derived from Table 2 .

$*, * *$ at $p<.05, p<.01$. 
users of urban agricultural parks in Seoul, Gyeonggi, and Jeonnam and determined which items are most needed by urban residents for garden management.

$58.4 \%$ of the respondents were female, and most were in their 50s (36.3\%), attended or graduated universities (41.6\%), had 4 household members (38.9\%), lived in apartments of 5 stories or more $(76.1 \%)$, and were currently gardening (83 subjects, $73.5 \%$ ).

For general awareness on gardens in urban parks, 108 subjects (95.6\%) responded that gardens are needed in urban parks, for reasons such as psychological and emotional health of urban residents $(86,26.2 \%)$ and for interaction and friendship with family and neighbors (76, 23.2\%). For use of garden crops, most were private sales (96 subjects, $64.4 \%$ ), and both private and group sales preferred to partially donate their crops. Currently 83 subjects (73.5\%) were using gardens, mostly communal gardens operated by public institutions (30.1\%), and 37 (44\%) were using gardens 2-3 times a week. They stayed for 1-2 hours (46.3\%) mostly on weekends such as Saturdays (21.3\%) and Sundays (16.3\%). 22 subjects (26.5\%) were gardening by themselves or only by their spouse, and 26 (55.4\%) were just talking to one another to interact among users. Most subjects $(38,45.8 \%)$ shared the harvested crops with family and neighbors. $72.3 \%$ responded they were very satisfied after urban gardening activities, $24.1 \%$ responded they were satisfied, and 3.6\% responded they were neutral, indicating that most were generally satisfied. Except 6 respondents $(5.3 \%)$, all $(107,94.7 \%)$ showed the intention to participate in urban gardens in the future, showing that they had high interest in urban gardens.

$\mathrm{KMO}$, the coefficient determining the adequacy of samples, was .848, and the significance level was .001, showing a value close to 1 and a value over 0.5 and thus proving validity of factor analysis. Based on the similarity of extracted items, the factors were named composition elements (Factor 1), management items (Factor 2), convenience elements (Factor 3), and operational facilities (Factor 4). Out of total 18 items necessary for creation and management of gardens, all except $x 5$ (water fountains and irrigation facilities), x6 (resource-utilized composting facilities), x10 (convenience facilities for the disabled), y5 (small groups among users), and y7 (community programs for users) did not show a statistically significant difference, but Pearson's $\mathrm{R}$ showed that all items had correlation and thus were statistically significant.

The desire of urban residents to participate in urban agriculture is increasing, and recently various forms of urban agriculture are developing. However, due to insufficient garden space with the land price issue and limited resources in urban areas, there are limitations in participation of urban residents. Therefore, by expanding the application scope of gardens and urban parks or creating new urban agricultural parks, urban residents will be able to actively use and participate in urban gardens while also externally extending the currently insufficient urban gardens. Accordingly, to promote use of urban agricultural parks and increase citizen satisfaction, it is necessary to consider additional policies to create parks for experience beyond appreciation by setting up a garden for urban agriculture and adding experience-based facilities and contents for continued operation. It is also necessary to review creation of urban agricultural parks in relation to the lack of garden space in urban areas as well as external extension of gardens. By creating urban agricultural parks that can be actually used with active participation of urban residents based on their needs beyond parks that are just appreciated, it will be possible to develop important policy measures to promote community recovery and urban agriculture.

This study is limited in that it has failed to provide data on public gardens of all urban agricultural parks in Korea. A bigger sample size will produce different results. Nonetheless, the results have reflected the needs of actual users in establishing the plans to operate urban gardens, thereby having great utility value as the basic data for continuous garden management. Based on the results of this study, further research can be conducted to derive detailed elements that can guarantee sustainability of urban gardens and suggest high-quality data for management of gardens in urban agricultural parks. This will contribute to sustainable use of urban agriculture by establishing desirable measures to operate and maintain public gardens. 


\section{References}

Chae, Y., K.S. Han, I.K. Hong, S.M. Lee, Y.B. Jung, and B.K. Lee. 2019. A survey on user's perception on the management of eco-friendly urban garden using companion plants. J. People Plants Environ. Vol. 22 (Suppl. II ):158

Hong, I.K., H.K. Yun, Y.B. Jung, and S.M. Lee. 2021. A study on the perception of companion plants for eco-friendly urban agriculture among urban residents. J. People Plants Environ. 24(1):17-27. http://doi.org/10. 11628/ksppe.2021.24.1.17

Kang, J.H. 2016. Using statistical analysis according to the new spss program. Seoul, Korea: Crownbook Press.

Kim, S.M. 2014. A study on the consciousness of residents for making a small garden. Master's thesis, Gachon University, Seongnam, Korea.

Lee, J.I. 2015. Basic plan for the urban agriculture park in Gosangol, Daegu. Master's thesis, Yeungnam University, Daegu, South Korea.

Lee, P.Y. 2003. Understanding of research and analysis theory. Paju-si, Gyeonggi-do, South Korea: Free academy.

Ministry of Agriculture, Food and Rural Affairs(MAFRA). 2018. Establishment of the $5^{\text {th }}$ comprehensive plan for the second urban agriculture upbringing. Press release.
Nam, K.H. 2014. A study on the publicity of the urban park according to creating community gardens. Master's thesis, University of Seoul, Seoul, South Korea.

Oh, C.H, C.H. Ahn, B.Y. Shin, K.O. Lee, K.S. Kim, K.Y. Koo, G.W. Kim, H.S. Baek, M.J. Park, B.K. Jung, O.H. Kwon, J. Jang, S.M. Ban, H.C. Park, E.H. Park, S.H. Kim, Y. Wi, T.G. Kim, and J.W. Kim. 2013. A study on the master plan of urban agriculture in seoul, Agro in seoul, Seoul, Korea.

Oh, K.Y. 2012. A study on the development of urban agricultural park models. Local Administration Policy (Ministry of Public Administration and Security) 2(2): 85-105.

Park, E.H., E.H. Yoo. K.S. Han. Y.N Jang, S.J. Jeong, and D.K. Park. 2016. Utilization analysis on participants of functional vegetabel garden model for urban agriculture. J. Korean Soc. People Plants Environ. 19(5):393-401. https://doi.org/10.11628/ksppe.2016.19.5.393

Yoo, S.B. 2014. A study on the status and characteristics of urban community garden focused on urban publicness. Master's thesis, Seoul National University, Seoul, South Korea.

Yun, J.H. 2020. Survey on recognition of urban agricultural park by neighborhood park users. Master's thesis. Keimyung University, Daegu, Korea. 